\title{
EFFECT OF CERTAIN DIETARY VITAMINS SUPPLEMENTATION ON SOME PRODUCTIVE, REPRODUCTIVE AND HATCHING PERFORMANCE OF JAPANESE QUAIL UNDER EGYPTIAN SUMMER CONDITIONS
}

\author{
Mohamed M. El-Mekawy ${ }^{*}$, A.A. Askar, Zenat A. Ibrahim and M.M. Soliman \\ Poult. Dept., Fac. Agric., Zagazig Univ., Egypt
}

\begin{abstract}
This work was conducted to study the effect of dietary supplementation of vitamins A, E, C, $\mathrm{B}_{6}$ and $\mathrm{B}_{12}$ on some productive and reproductive traits of mature Japanese quails during hot summer season under Egyptian environmental conditions. A total number of 180 Japanese quail breeders (126 females and 54 males), 8 weeks old with nearly equal body weight (215 to 250 g) were randomly divided into six treatment groups (21 females and 9 males in each group). Birds in the first experimental group received the basal diet (without supplementation) used as control, while birds in $2^{\text {nd }}, 3^{\text {rd }}, 4^{\text {th }}, 5^{\text {th }}$ and $6^{\text {th }}$ groups, were received the basal diet supplemented with one of the following vitamins, A (5 mg / $\mathrm{kg}$ diet), E (150 mg $/ \mathrm{kg}$ diet), C (250 mg $/ \mathrm{kg}$ diet), $\mathrm{B}_{6}$ ( $3 \mathrm{mg} / \mathrm{kg}$ diet) or $\mathrm{B}_{12}(2 \mathrm{mg}$ $/ \mathrm{kg}$ diet), respectively. Egg production, egg quality, semen characteristics as well as hatchability (\%) and hatched chick performance were determined. Results indicated that the addition of vitamin $\mathrm{C}$ or $\mathrm{B}_{6}$ in the diets of Japanese quail layers, significantly $(\mathrm{P} \leq 0.01)$ improved egg number and feed conversion ratio (FCR) comparatively with those unsupplemented treatments, while egg mass values were improved significantly $(\mathrm{P} \leq 0.05)$ in layers fed diet supplemented with vitamin $\mathrm{E}$, $\mathrm{C}$, or $\mathrm{B}_{6}$ when compared with layers fed basal diet. The highest egg length value was obtained for hens fed diets supplemented with $150 \mathrm{mg}$ vitam. E / kg diet, while the lowest value was obtained with those fed diets supplemented with $3 \mathrm{mg}$ vitam. $\mathrm{B}_{6} / \mathrm{kg}$ diet when compared with control. Birds fed diet supplemented with $150 \mathrm{mg}$ vitam. E/kg diet recorded the lowest value of egg shape index comparatively with the control and other treatment groups. Japanese quail layers given $\mathrm{B}_{6}$ or $\mathrm{B}_{12}$ had significantly $(\mathrm{P} \leq 0.01)$ higher hatchablility values than those unsupplemented with vitamins. Semen characteristics studied [mass motility (\%), individual motility (\%) and dead sperm (\%)] were significantly (P $\leq 0.01)$ improved male Japanese quail fed diets supplemented with $\mathrm{A}, \mathrm{E}, \mathrm{C}$ and $\mathrm{B}_{6}$ in comparison with these supplemented with vitam. $\mathrm{B}_{12}$ and the control group. It could be concluded that supplementing quail breeder diet with vitamins $\mathrm{B}_{6}, \mathrm{E}$ and $\mathrm{C}$, improved the productive performance, while vitam. $\mathrm{B}_{6}$ gave the higher hatchability percentage. The best semen characteristics were obtained by vitam. E supplementation.
\end{abstract}

Key words: Vitamins, productive, performance, reproductive, semen, hatchability, quail.

\section{INTRODUCTION}

An important economical goal of the poultry industry is to increase the productivity. However, the productivity of this industry is threatened by climatic and physical stress (Dreiling et al., 1991). High temperature in poultry house

\footnotetext{
*Corresponding author: Tel. : +201000266654

E-mail address: mmfahmy_elmekkay@yahoo.com
}

reduced feed intake, body weight and feed efficiency. Furthermore, high ambient temperature causes the release of corticosterone and catecholmines. Corticoid steriods depress immune system function, reduce serum protein concentrations and increase blood glucose concentrations which have damaging effect on poultry performance by decreasing body weight 
gain and egg production. Therefore, maximum production requires the elimination of the deleterious impacts of environmental stressors (Dreiling et al., 1991; Bollengier et al., 1998).

There are numerous methods to alleviate the negative effects of high environmental temperature on performance of poultry. Due to the fact that, it is expensive to cool animal buildings, such methods are focused mostly on dietary manipulation, critical essential amino acids (Yanming and Baker, 1993), minerals and vitamins (Moreng, 1980), feed additives and growth promoters (Teeter, 1995).

Essential functions of vitam. A in growth, visual development and reproductive physiology are well established in poultry, as well as in other animals. Several workers revealed a beneficial effect of vitam. A supplementation on egg production and egg shell strength in stressed laying hens as a result of many important functions of vitam. A in the body including vision, differentiation of epithelial cells and reproduction (McDowell, 1989; Sahin et al., 2001; Lin et al., 2002).

Vitamin $\mathrm{E}$ is an excellent biological chain breaking antioxidant that protects cells and tissue from lipoperoxidative damage induced by free radicals (Jena et al., 2013) and has multieffects on fortification of immune system (Kaiser et al., 2012; Nayaka et al., 2012). The feeding of vitamin $\mathrm{E}$ reduces oxidative stress and lipid peroxidation (Eid et al., 2002), and increases immunoglobulin in broiler chicken, turkey, and ducks (Gore and Qureshi, 1997; Selim et al., 2012).

The influence of supplementary vitamin $C$ on the harmful effect of physiological stress has met with rising interest in recent times. The physiological requirement of vitamin $\mathrm{C}$ has been shown to exceed the vitamin $\mathrm{C}$ synthesizing ability of chicken under stressful condition like high ambient temperature, humidity, production rate and parasitic infestation (Sahin and Kucuk, 2001; Sahin et al., 2002a).

Pyridoxine (vitamin $\mathrm{B}_{6}$ ) has an important role in amino acid, carbohydrate and fatty acid metabolism and also plays a major role in energy production through citric acid cycle
(McDowell, 1989). Vitamin $B_{6}$ is essential for brain development and function and helps the body to synthesize serotonin, norepinephrine, and melatonin hormones (Pond et al., 1995). Deficiency of pyridoxine leads to early embryonic death.

Vitamin $B_{12}$ is an essential component of several enzyme systems that carry out a number of very basic metabolic functions in the animal's body (McDowell, 1989). This vitamin plays a central role in normal functions of the brain and the nervous system, in the homocystein metabolism, in the blood function, energy metabolism, cell division and functions of the immune system (EFSA, 2009 and 2010).

The objective of this study was to evaluate the effect of adding vitamins $\mathrm{A}, \mathrm{E}, \mathrm{C}, \mathrm{B}_{6}$ and $\mathrm{B}_{12}$ to Japanese quail breeder diets on productive performance, fertility, hatchability and some semen traits under summer conditions of Egypt.

\section{MATERIALS AND METHODS}

The current experiment was carried out at the Poultry Research Farm, Poultry Department, Faculty of Agriculture, Zagazig University, Zagazig, Egypt, during the period from June till August under Egyptian summer conditions.

A total number of 126 females and 54 males of Japanese quails at 8 weeks of age with nearly equal body weight were randomly divided into six treatment groups (21 females and 9 males in each group). Each group of birds was subdivided into 3 replicates, each of 7 females and 3 males. Each replicate was housed in one cage under the same managerial conditions. The first $\left(1^{\text {st }}\right)$ group received the basal diet (without supplementation) and used as control. While, the $2^{\text {nd }}, 3^{\text {rd }}, 4^{\text {th }}, 5^{\text {th }}$ and $6^{\text {th }}$ groups received the basal diet supplemented with one of the following vitamins: vit. A (5 mg / $\mathrm{kg}$ diet), vit. E (150 mg $/ \mathrm{kg}$ diet), vit. C (250 mg / $\mathrm{kg}$ diet), vit. $\mathrm{B}_{6}$ (3 mg $/ \mathrm{kg}$ diet) or vit. $\mathrm{B}_{12}(2 \mathrm{mg} / \mathrm{kg}$ diet), respectively. Composition and calculated analysis of the experimental basal diet are shown in Table 1. The basal experimental diet was formulated to cover the nutritional requirements of layer Japanese quails throughout the experimental period (from 8 to 20 weeks of age) according to NRC (1994). Vitamins A, E, C, $B_{6}$ and $B_{12}$ were purchased from Multivita Company, Sixth of 
October City, Giza Governorate, Egypt in the forms of: vitam. A (retinol), vitam. E (DL- $\alpha-$ Tocopherol), vitam. C (ascorbic acid), vitam. $\mathrm{B}_{6}$

Table 1. Composition and calculated analysis of (pyridoxine) and vitam. $\mathrm{B}_{12}$ (cyanocobalamin), respectively.

\begin{tabular}{lc}
\hline Ingredient & Percentage \\
\hline Yellow corn & 59.79 \\
Soybean meal (44\%) & 25.05 \\
Protein Concentrate (52\%) & 07.80 \\
Corn oil & 01.49 \\
Calcium carbonate & 04.99 \\
Limestone & 00.17 \\
Dl-Methionine & 00.06 \\
Lysine & - \\
Premix* & 00.30 \\
Salt & 00.35 \\
Total & 100.0 \\
Calculated analysis (\%) & \\
Crude protein & 20.00 \\
ME kcal/kg & 2900 \\
Lysine & 01.00 \\
Methionine+cysteine & 00.45 \\
Calcium & 02.50 \\
Available phosphorus & 00.35 \\
\hline
\end{tabular}

*: Vitamin and mineral premix per kg of diet: Each kilogram of diet contains : Vitam. A,4mg., D3, 2500 I.U., E,

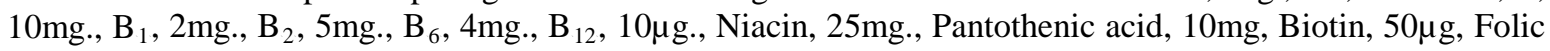

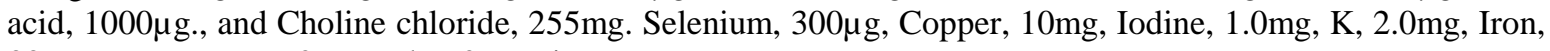
33mg, Manganese, 60mg and, 60mg Zinc.

Birds were fed ad libitum and fresh water was available throughout the experiment. Artificial light source was used, giving a total of 16 hr., of light per day. The maximum and minimum ambient temperatures during the experimental period (12 weeks) were daily recorded at noon $(12.00 \mathrm{pm})$. The ambient temperature ranged between 23.6 and $34.7^{\circ} \mathrm{C}$, while the relative humidity (RH) was between 31.8 and $80.7 \%$.

Egg number and egg weight were daily recorded. Feed consumption was weekly calculated. Egg mass was calculated by multiplying egg number by average egg weight. Feed conversion ratio (g feed/g egg) was calculated after subtracting the male consumption (one third) from the total amount of the feed consumed.

At the end of experiment (20 weeks of age) three males from each treatment group were used for semen evaluation. Semen samples were collected according to Burrows and Quinn (1937). Sperm motility (\%) was determined according to the percentages of spermatozoa moving forward motion according across the field of vision with a normal vigorous swimming motion. Dead spermatozoa (\%) were determined according to Hackett and Macpherson (1965) using nigrosin-eosin staining. 
After 12 weeks of the experimental treatment, a total number of 540 quail eggs were collected from all experimental groups (90 eggs per group) for a period of 7 days. Eggs were gathered daily and stored at large end up in plastic trays at $14^{\circ} \mathrm{C}$. Eggs were warmed to room temperature before placing in automatic incubator at $37^{\circ} \mathrm{C}$ and $65-75 \% \mathrm{RH}$ and turned through $45^{\circ}$ every $1 \mathrm{hr}$. At the $14^{\text {th }}$ day of incubation, eggs were kept till hatching at $37.5^{\circ} \mathrm{C}$ and $70 \% \mathrm{RH}$ without turning. After hatching, chicks from every treatment group were counted and individually weighed to determine hatchability percentage of fertile eggs, chick weight and relative chick weight. Eggs that failed to hatch were broken out to determine the number of fertile eggs, as well as, percentages of early and late embryonic mortality depending on the number of fertile eggs.

Analysis of variance for data of random design was accomplished using the SAS General Liner Models Procedure (SAS Institute, 1996). The model was assessed for different traits according to Snedecor and Cochran (1982). The statistical fixed model used was: $\mathrm{Y}_{\mathrm{ij}}=\mu+\mathrm{T}_{\mathrm{i}}{ }_{\mathrm{eij}}$

Where:

$\mathrm{Y}_{\mathrm{ij}}=$ an observation.

$\mu=$ Overall mean.

$\mathrm{T}_{\mathrm{i}}=$ the fixed effect of treatment.

$\mathrm{e}_{\mathrm{ij}}=$ Random error.

Duncan's new multiple range test was used to test the differences among the means according to Duncan (1955).

\section{RESULTS AND DISCUSSION}

\section{Productive Performance}

Results in Table 2 show that, the addition of vitamin C (250 $\mathrm{mg} / \mathrm{kg}$ diet) or $\mathrm{B}_{6}(3 \mathrm{mg} / \mathrm{kg}$ diet) in the diets of Japanese quail layers significantly $(\mathrm{P} \leq 0.01)$ improved egg number and feed conversion ratio (FCR) followed by the groups supplemented with vit. $\mathrm{E}, \mathrm{A}$ and $\mathrm{B}_{12}$, respectively comparatively with unsupplemented one. Egg mass values were significantly improved $(\mathrm{P} \leq 0.05)$ in layers fed diet supplemented with vitamin $\mathrm{C}$, $\mathrm{E}$, or $\mathrm{B}_{6}$ when compared with layers fed control diet. Egg mass increased by $22.74,22.18$ and $14.77 \%$ in layers fed diets supplemented with $\mathrm{C}, \mathrm{E}$ and $\mathrm{B}_{6}$, respectively.

However, egg weight was not significantly affected due to vitamins supplementation. Egg number improved by 16.13 and $19.92 \%$ in layers fed diets supplemented with vitam. $C$ and $B_{6}$, respectively compared with those fed unsupplemented diet. The corresponding values of FCR were 15.58 and $14.93 \%$, respectively.

With respect to dietary ascorbic acid (vit. C) Supplementation under heat stress in terms of better performance of poultry, results of the present study are in agreement with many investigators (McMurry et al., 1980; McDowell, 1989; Gonzalez et al., 1995). Similarly to the present study Sahin et al. (2003) found that vitamin $C$ and $E$ supplementation improved the performance namely live weight, egg production in laying Japanese quails reared under high ambient temperature. It is well known that growth rate and egg production decreased when ambient temperature goes above therms neutral zone (Kafri, 1989). At temperature above or below therms neutral zone, corticosteroid secretion increases as a response to stress (Sahin et al., 2001). Kultu and Forbes (1993) reported that, ascorbic acid reduces the synthesis of corticosteroid hormones in birds by decreasing synthesis and secretion of corticosteroid, vitamin $\mathrm{C}$ alleviates the negative effects of stress. It has been also postulated that, the improved performance of laying hens results from a decrease in protein derived gluconeogenesis (Orban et al., 1993).

In the present study, dietary vitamin $\mathrm{E}$ supplementation resulted in a better egg mass. Heat stress causes oxidative damage of the membrane of hepatic cells leading to decrease in plasma egg yolk precursor protein (Siegel, 1995). This kind of negative effect was alleviated by dietary vitamin E supplementation. It was speculated that, the positive influence of vitamin E supplementation on egg production may be explained by enhanced synthesis of egg yolk precursors in liver through protecting the liver from lipid peroxidation and damag to cell 
membranes. This was previously confirmed in hens by Bollengier et al. (1998). by Abd El-Galil and Abd El-Samad (2004) and Ciftci et al. (2005). The present results confirm

Similar results were obtained by laying Japanese quail reared under heat stress $\left(34^{\circ} \mathrm{C}\right)$

Table 2. Effect of dietary vitamins $A, E, C, B_{6}$ and $B_{12}$ supplementation (Mean \pm SE) on productive performance of Japanese quail breeder hens

\begin{tabular}{|c|c|c|c|c|c|}
\hline \multirow[b]{2}{*}{ Treatment } & \multicolumn{5}{|c|}{ Trait } \\
\hline & $\begin{array}{l}\text { Average egg } \\
\text { weight (g) }\end{array}$ & $\begin{array}{c}\text { Egg number } \\
\text { (monthly) }\end{array}$ & $\begin{array}{l}\text { Egg mass } \\
\text { (monthly) }\end{array}$ & $\begin{array}{l}\text { Feed consumption } \\
\text { (g/hen/week) }\end{array}$ & $\begin{array}{c}\text { Feed conversion ratio } \\
\text { (g feed : g egg mass) }\end{array}$ \\
\hline Control & $12.19 \pm 0.29$ & $20.08 \pm 0.30^{c}$ & $244.67 \pm 6.18^{c}$ & $201.62 \pm 2.44^{\mathrm{a}}$ & $3.08 \pm 0.08^{\mathrm{a}}$ \\
\hline A & $12.77 \pm 0.20$ & $21.40 \pm 0.96^{\mathrm{bc}}$ & $272.96 \pm 8.07^{\mathrm{abc}}$ & $187.45 \pm 2.00^{c}$ & $2.75 \pm 0.05^{\mathrm{ab}}$ \\
\hline $\mathbf{E}$ & $12.57 \pm 0.20$ & $22.32 \pm 0.62^{\mathrm{bc}}$ & $280.81 \pm 12.22^{\mathrm{ab}}$ & $188.46 \pm 4.77^{\mathrm{bc}}$ & $2.88 \pm 0.09^{\mathrm{ab}}$ \\
\hline C & $12.84 \pm 0.36$ & $23.32 \pm 0.90^{\mathrm{ab}}$ & $298.94 \pm 3.24^{\mathrm{a}}$ & $194.19 \pm 2.62^{\mathrm{abc}}$ & $2.60 \pm 0.06^{\mathrm{b}}$ \\
\hline $\mathbf{B}_{6}$ & $12.47 \pm 0.15$ & $24.08 \pm 0.15^{\mathrm{a}}$ & $300.32 \pm 5.49^{a}$ & $196.49 \pm 1.62^{\mathrm{ab}}$ & $2.62 \pm 0.07^{\mathrm{b}}$ \\
\hline $\mathbf{B}_{12}$ & $12.35 \pm 0.32$ & $21.48 \pm 1.02^{\mathrm{bc}}$ & $265.60 \pm 16.82^{\mathrm{bc}}$ & $190.39 \pm 0.98^{\mathrm{bc}}$ & $2.89 \pm 0.19^{\mathrm{ab}}$ \\
\hline Sig. & NS & $*$ & $*$ & $*$ & $*$ \\
\hline
\end{tabular}

Means in the same column within each classification bearing different letters are significantly different. ${ }^{*}=(\mathrm{P} \leq$ 0.05), and NS = Not significant.

the previous results of Abdel-Maksoud (2006) and El-Mallah et al. (2011) who found that supplemental vitamin E increased egg production by alleviating the adverse effect of high ambient temperature in laying hens during summer months.

Feed intake was significantly affected $(\mathrm{P} \leq$ 0.05 ) by dietary vitamins supplementation. It could be noticed that, feed intake was decreased in birds fed diet supplemented with vitamins of $\mathrm{A}, \mathrm{E}$ and $\mathrm{B}_{12}$ while it was insignificantly decreased in hens fed diets supplemented with vit. $\mathrm{C}$ and $\mathrm{B}_{6}$. These findings are in agreement with those obtained by Sahin et al. (2003) who found that feed intake was decreased by vitamin $\mathrm{C}$ and $\mathrm{E}$ supplementation in laying Japanese quails diet reared under high ambient temperature.

\section{Egg Quality}

As shown in Table 3, statistical analysis revealed significant $(\mathrm{P} \leq 0.01)$ effects of dietary treatments on egg length and egg shape index. Egg width, egg shell thickness and yolk diameter were not significantly affected with dietary treatments. It could be noticed that the highest egg length value was obtained for hens fed diets supplemented with $150 \mathrm{mg}$ vit. E $/ \mathrm{kg}$ diet, while the lowest value was obtained by hens fed diets supplemented with $3 \mathrm{mg}$ vit. $\mathrm{B}_{6}$ $/ \mathrm{kg}$ diet when compared with control. The remaining other treatment groups $\left(\mathrm{A}, \mathrm{C}\right.$ and $\left.\mathrm{B}_{12}\right)$ had insignificant effect when compared with control.

It is worthy noting that, layers fed diet supplemented with $150 \mathrm{mg}$ vit. E $/ \mathrm{kg}$ diet recorded the lowest value of egg shape index comparatively with control and other treatment groups. Japanese quail layer fed diet supplemented with $150 \mathrm{mg}$ vit. E / $\mathrm{kg}$ diet or 250 $\mathrm{mg}$ vit. $\mathrm{C} / \mathrm{kg}$ diet showed insignificantly higher value of egg shell thickness followed by those fed diet supplemented with $5 \mathrm{mg}$ vit. A $/ \mathrm{kg}$ diet and $2 \mathrm{mg}$ vit. $\mathrm{B}_{12} / \mathrm{kg}$ diet when compared with control (Table 3). Yolk diameter was numerically increased due to vitamins supplementation in Japanese quail layers diet as compared with unsupplemented diet.

Our results are in agreement with those obtained by Abdou (2009) who reported that exterior egg quality traits were improved with adding vitamins $\mathrm{E}$ and $\mathrm{A}$ either alone or in a 
combination and the improvements were more pronounced for Japanese quail hens fed on 300 mg vit. E /kg diet. While, Sahin et al. (2002b) and Abou-Kassem (2010) found significant $(\mathrm{P} \leq$
0.05) improvement in egg shell thickness of Japanese quail when the diet contained vit.E (250 to $500 \mathrm{mg} / \mathrm{kg}$ diet).

Table 3. Effect of dietary vitamins $A, E, C, B_{6}$ and $B_{12}$ supplementation (Mean \pm SE) on egg quality traits of Japanese quail breeder hens

Egg quality

\begin{tabular}{lcccccc} 
Treatment & $\begin{array}{c}\text { Egg weight } \\
\mathbf{( g )}\end{array}$ & $\begin{array}{c}\text { Egg length } \\
\mathbf{( m m})\end{array}$ & $\begin{array}{c}\text { Egg width } \\
\mathbf{( m m})\end{array}$ & $\begin{array}{c}\text { Shell thickness } \\
\mathbf{( m m})\end{array}$ & $\begin{array}{c}\text { Egg shape } \\
\text { index }(\mathbf{m})\end{array}$ & $\begin{array}{c}\text { Yolk diameter } \\
(\mathbf{m m})\end{array}$ \\
\hline Control & $12.44 \pm 0.32$ & $33.46 \pm 0.21^{\mathrm{bc}}$ & $26.52 \pm 0.08$ & $0.22 \pm 0.00$ & $79.26 \pm 0.13^{\mathrm{a}}$ & $24.99 \pm 0.08$ \\
$\mathbf{A}$ & $12.80 \pm 0.16$ & $33.40 \pm 0.09^{\mathrm{cd}}$ & $26.50 \pm 0.11$ & $0.23 \pm 0.01$ & $79.34 \pm 0.14^{\mathrm{a}}$ & $24.52 \pm 1.17$ \\
$\mathbf{E}$ & $13.11 \pm 0.03$ & $34.13 \pm 0.18^{\mathrm{a}}$ & $26.43 \pm 0.09$ & $0.24 \pm 0.01$ & $77.44 \pm 0.73^{\mathrm{b}}$ & $25.76 \pm 0.04$ \\
$\mathbf{C}$ & $12.46 \pm 0.03$ & $33.11 \pm 0.03^{\mathrm{cd}}$ & $26.51 \pm 0.06$ & $0.26 \pm 0.02$ & $80.06 \pm 0.19^{\mathrm{a}}$ & $24.47 \pm 0.08$ \\
$\mathbf{B}_{\mathbf{6}}$ & $12.47 \pm 0.02$ & $33.01 \pm 0.04^{\mathrm{d}}$ & $26.35 \pm 0.03$ & $0.22 \pm 0.00$ & $79.81 \pm 0.24^{\mathrm{a}}$ & $26.63 \pm 0.06$ \\
$\mathbf{B}_{\mathbf{1 2}}$ & $12.88 \pm 0.23$ & $33.83 \pm 0.10^{\mathrm{ab}}$ & $26.84 \pm 0.08$ & $0.23 \pm 0.00$ & $79.34 \pm 0.13^{\mathrm{a}}$ & $26.70 \pm 0.11$ \\
Sig. & $\mathrm{NS}$ & $* *$ & $\mathrm{NS}$ & $\mathrm{NS}$ & $* *$ & $\mathrm{NS}$ \\
\hline
\end{tabular}

Means in the same column within each classification bearing different letters are significantly different. ${ }^{* *}=(\mathrm{P}$ $\leq 0.01$ ), and NS = Not significant.

The results obtained are in partially agreement with those of El-Mallah et al. (2011) who found that, both level of vit.E (20 or 40mg $/ \mathrm{kg}$ diet) significantly improved shell thickness and decreased shape index and yolk color than the control. Similar results were reported by Engelmann et al. (2001), Abd El-Galil and Abd El-Samad (2004) and El-Sheikh and Salama (2010).

In this connection, the achieved improvement in shell thickness may be due to enhancement of calcium bioavailability by the action of supplemental vit. E. Moreover, vit. E addition was stated to influence the oestradiol dependent mechanisms by exerting a direct effect on oestradiol or indirect effect through maintaining more normal function of cellular processes regulating oestradiol and restoration of estrogen secretion (Bollengier et al., 1998). Oestrdiol has a role on circulating calcium through the control of synthesis of 1, 2, 5 hydroxy cholecalciferol (Taylor and Darke, 1984), the active cholecalciferol metabolite that regulates calcium absorption. Circulating calcium and estrogen concentration are highly correlated in laying hens (Tojo and Huston, 1980).
With respect to dietary ascorbic acid supplementation under heat stress, the obtained results agreed with those of Pavlik et al. (2009) who found that exposure of hens to high temperatures results in significant decrease in egg quality (shell weight, shell thickness, and specific gravity) when the birds were exposed to heat stress. This finding could be due to reduction in feed consumption. The adverse effect of high environmental temperature on egg shell quality has been well documented (Mahmoud et al., 1996). The decrease in shell quality in the current study may be partially due to a reduction in plasma calcium level. Since the plasma calcium level was significantly decreased in laying hens when the birds were exposed to high temperature as reported by (Mahmoud et al., 1996). Also, Desoky (2008) stated that dietary supplementation of vitam. C (200 mg/kg diet) or vitam. E (150 mg/kg diet) either alone or its combination showed high ability of alleviating the negative effect of heat stress and improved egg quality.

\section{Egg Components}


In view of the result in Table 4, it is clearly noted that, the addition of different dietary vitamins $\left(\mathrm{A}, \mathrm{E}, \mathrm{C}, \mathrm{B}_{6}\right.$ and $\mathrm{B}_{12}$ ) in the current study had no significant effect on shell, albumin and yolk percentages. However, shell and yolk percentages and yolk diameters were numerically increased due to vitamins supplementation in Japanese quail layer diets as compared with unsupplemented one.

Table 4. Effect of dietary vitamins A, E, C, $B_{6}$ and $B_{12}$ supplementation (Mean $\pm S E$ ) on egg components percentage of Japanese quail breeder hens

\begin{tabular}{lccc}
\hline Treatment & Shell percent & Albumin percent & Yolk percent \\
\hline Control & $7.86 \pm 0.20$ & $61.09 \pm 0.11$ & $31.05 \pm 0.09$ \\
A & $9.24 \pm 0.08$ & $56.62 \pm 0.60$ & $34.15 \pm 0.62$ \\
E & $9.05 \pm 0.35$ & $54.07 \pm 0.25$ & $36.88 \pm 0.44$ \\
C & $8.49 \pm 0.36$ & $58.27 \pm 0.26$ & $33.24 \pm 0.11$ \\
B $_{\mathbf{6}}$ & $9.78 \pm 0.31$ & $57.82 \pm 0.19$ & $32.40 \pm 0.47$ \\
B $_{\mathbf{1 2}}$ & $9.03 \pm 0.30$ & $53.80 \pm 0.69$ & $37.17 \pm 0.71$ \\
Sig. & NS & NS & NS \\
\hline
\end{tabular}

This results may indicate that laying quails do not require high dietary levels of $\mathrm{A}, \mathrm{E}, \mathrm{C}, \mathrm{B}_{6}$ and $\mathrm{B}_{12}$ vitamins which may provide some evidence that the vitamins content of the ingredients itself, can meet the requirements of the laying quails so that extra supplementation might not be required to obtain high egg quality traits. Therefore, dietary sources of vitamins may have contributed to the apparent effects of the vitamins ( $\mathrm{A}, \mathrm{E}, \mathrm{C}, \mathrm{B}_{6}$ and $\mathrm{B}_{12}$ ) on egg quality traits. It is possible that the improvements of yolk and shell percentages are related to stimulatory effects of vitamins supplementation on growth of the female reproductive system. This finding agreed with the previous results of $\mathrm{Fu}$ et al. (2000) who reported an enhanced growth of female quail reproductive system accompanied with high levels of follicle stimulatory hormone (FSH) by feeding vitam. A. On the other hand, AbdelFattah and Abdel-Azeem (2007) showed high egg quality traits of quail egg by feeding different dietary levels of vitam. E with or without thyroid hormone (T4) to laying quails.

It is widely accepted that, high dietary levels of vitam. A and vitam. E could interact with vitam. $\mathrm{D}_{3}$ metabolism. This relationship was more obvious for the exterior egg quality traits (shell percentage and shell weight) and to lesser extent in case of interior egg traits. Although most workers have generally agreed on the existence of nutritional relationships among fat soluble vitamins in general and nutritional interactions among vitam. A, D3 and vitam. E in particular (Aburto and Britton 1998; Grobas et al., 2002; Amiri et al., 2006).

Our findings are in line with those of Abdou (2009) who found that interior egg qualities were not improved by adding vitam. A and vitam. E either alone or in a combination. AbouKassem (2010) reported that quail layers fed diets supplemented with vitam. E produced eggs with significantly $(\mathrm{P} \leq 0.01)$ lower albumin $(\%)$, higher yolk and shell percentages. On the other hand, Ajakaiye et al. (2011) found that, egg yolk and egg albumin weights in groups administrated vitamins $\mathrm{E}$ and $\mathrm{E}+\mathrm{C}$ were significantly $(\mathrm{P} \leq$ 0.05 ) high as compared with the control group. With regared to vitamin $\mathrm{B}_{12}$, Halle and Ebrahem (2012) noted that supplementation of diets with vit. $\mathrm{B}_{12}$ or cobalt or both additives did not dirctly improve the egg composition or the yolk color.

\section{Reproductive Performance}

Results in Table 5 illustrate that, fertility percentages were insignificantly affected due to dietary supplementation by different vitamins when compared with unsupplemented diet. This 
finding may be related to the improvement of egg and semen quality with feed additives in this study. It could be noticed that the best value of fertility percentage $(89.78 \%)$ was recorded in eggs collected from quail layers fed diet

Table 5. Effect of dietary vitamins $A, E, C, B_{6}$ and $B_{12}$ supplementation (Mean $\pm S E$ ) on percentages of fertility and hatchability of Japanese quail eggs

\begin{tabular}{lccc}
\hline Treatment & \multicolumn{3}{c}{ Trait } \\
\cline { 2 - 4 } & Fertility (\%) & Hatchability from fertile eggs (\%) & Chicks weight at hatch \\
\hline Control & $84.60 \pm 0.63$ & $82.50 \pm 1.44^{\mathrm{c}}$ & $9.08 \pm 0.30$ \\
Vit. A & $85.87 \pm 2.77$ & $85.00 \pm 1.44^{\mathrm{bc}}$ & $9.00 \pm 0.15$ \\
E & $89.78 \pm 3.42$ & $86.67 \pm 1.66^{\mathrm{abc}}$ & $9.20 \pm 0.17$ \\
C & $88.78 \pm 0.99$ & $87.50 \pm 2.50^{\mathrm{abc}}$ & $9.25 \pm 0.69$ \\
B $_{\mathbf{6}}$ & $88.52 \pm 4.67$ & $91.00 \pm 1.50^{\mathrm{a}}$ & $9.09 \pm 0.37$ \\
B $_{\mathbf{1 2}}$ & $87.44 \pm 5.75$ & $89.33 \pm 0.47^{\mathrm{ab}}$ & $9.05 \pm 0.26$ \\
Sig. & $\mathrm{NS}$ & $*$ & $\mathrm{NS}$ \\
\hline
\end{tabular}

Means in the same column within each classification bearing different letters are significantly different. $*=(\mathrm{P} \leq 0.05)$ and NS = Not significantly.

Contrary to the present results, Lin et al. (2002) added $80 \mathrm{mg}$ vitam. E $/ \mathrm{kg}$ diet, Lin et al. (2005) with a level of $160 \mathrm{mg}$ vitam. E $/ \mathrm{kg}$ diet and Abou-Kassem (2010) added $250 \mathrm{mg}$ vitam. $\mathrm{E} / \mathrm{kg}$ diet in Japanese quail and reported improve in fertility percentage. They postulated that fertility percentage might be improved by supplementing these vitamins. However, Hooda et al. (2007) concluded that supplemental of 75 $\mathrm{mg}$ vitam. E $/ \mathrm{kg}$ in Japanese quail's diet did not effect on fertility percentage.

It was noticed from Table 5 , that hatchability percentage was significantly increased $(\mathrm{P} \leq 0.05)$ by dietary supplementation of vitamins $\mathrm{A}, \mathrm{E}$, and $C$ when compared with unsupplemented diet (control group). However, Japanese quail layers given $B_{6}$ or $B_{12}$ had significantly $(P \leq 0.01)$ highest hatchablility values for eggs than those unrecieving vitamins. This finding may be related to improvement of egg quality. It is clearly observed that the best value of hatchability percentage $(91.00 \%)$ was obtained with eggs hatched from quail layers fed diet supplemented with $\mathrm{B}_{6}$, while the lowest one $(82.50 \%)$ was recorded with egg produced from quail layers fed basal diet group. Also, the results showed that treated groups were better supplemented with $150 \mathrm{mg}$ vitam. E/kg diet, while the lowest fertility value $(84.60 \%)$ was recorded with eggs produced from quail layer fed unsupplemented diet. 
Each of mass motility (\%), individual motility (\%) and dead sperm (\%) were significantly (P $\leq$ 0.01 ) improved in male Japanese quail fed diets supplemented with all vitamins studied except vitam. $B_{12}$ where the improvements were not significant (Table 6).
It could be observed that the best semen characteristics values were recorded in males fed diet supplemented with vitamin $\mathrm{E}$ while, the worst values recorded by unsupplemented one.

Table 6. Effect of dietary vitamins $A, E, C, B_{6}$ and $B_{12}$ supplementation (Mean $\pm \mathrm{SE}$ ) on some semen trait percentages of Japanese quail males

\begin{tabular}{lccc}
\hline Treatment & \multicolumn{3}{c}{ Trait percentages } \\
\cline { 2 - 4 } & Mass motility & Individual motility & Dead sperm \\
\hline Control & $72.50 \pm 1.44^{\mathrm{d}}$ & $74.83 \pm 1.30^{\mathrm{d}}$ & $27.50 \pm 1.44^{\mathrm{a}}$ \\
Vit. A & $77.50 \pm 1.44^{\mathrm{bc}}$ & $79.50 \pm 1.44^{\mathrm{bc}}$ & $22.50 \pm 1.44^{\mathrm{bc}}$ \\
$\mathbf{E}$ & $81.50 \pm 0.87^{\mathrm{a}}$ & $83.67 \pm 0.88^{\mathrm{a}}$ & $18.50 \pm 0.87^{\mathrm{d}}$ \\
$\mathbf{C}$ & $79.00 \pm 0.58^{\mathrm{ab}}$ & $81.33 \pm 0.73^{\mathrm{ab}}$ & $21.00 \pm 0.58^{\mathrm{cd}}$ \\
$\mathbf{B}_{6}$ & $76.50 \pm 0.87^{\mathrm{bc}}$ & $78.67 \pm 0.88^{\mathrm{bc}}$ & $23.50 \pm 0.87^{\mathrm{bc}}$ \\
$\mathbf{B}_{12}$ & $75.00 \pm 0.58^{\mathrm{cd}}$ & $77.17 \pm 0.44^{\mathrm{cd}}$ & $25.00 \pm 0.58^{\mathrm{ab}}$ \\
Sig. & $* *$ & $* *$ & $* *$ \\
\hline
\end{tabular}

Means in the same column within each classification bearing different letters are $* *=(P \leq 0.01)$.

These results indicated that, the supplementation of vitamins might improve the function of the testis. Improvement of sperm quality by vitamin E supplementation associated with deoxidized spermatozoa (Fujihara and Howarth, 1978). Adding 80 and $160 \mathrm{mg}$ vitam. E tended to increase plasma testosterone concentration and sperm concentrations (Lin et al., 2005). A Similar reports indicated that vitam. E played an important role in spermatogenesis (Marin-Guzmen et al., 1997).

The positive effect of ascorbic acid can be attributed to the fact that it is very efficient antioxidant and scavenges Reactive Oxygen Species (ROS) which are noxious to the sperm. Ascorbic acid is a dominant antioxidant when peroxyl radicals are located in the gaseous phase (Donoghue and Donoghue, 1997). Ascorbic acid is also, required for male hormones production like testosterone, which is essential for the reproductive performance (Sonmez et al., 2005).

The present results are in agreement with those of Hood (1999) who reported that heat exposure caused an increase in the percentage of dead sperms and decrease in the sperm quality index. However, Monsi and Onitchi (1991) supplemented the feed of heat stressed broilers breeders with $0,125,250$, and $500 \mathrm{mg}$ ascorbic $\mathrm{acid} / \mathrm{kg}$ diet and found that each of semen volume, total sperm and motile sperms per ejaculate were significantly increased due to the addition of ascorbic acid. Noll (1997) reported that, improvement in sperm cell concentrations in males when Turkey breeder diets were supplemented with $200 \mathrm{mg} / \mathrm{kg}$ of vitamin C. Similarly, Ezzat et al. (2011) found that, supplementation of vitamin C (200 mg/kg diet) of Matrouh cockerels improved sperm motility and decreased dead spermatozoa compared with the control. Recently, Jabbar et al. (2015) revealed that, ascorbic acid supplementation had better resistance against the Reactive Oxygen Species (ROS) damag in terms of live sperm, morphological defects and also for fertility.

Concerning supplemented Japanese quail's diet with vitam. E, our results confirm those obtained by Biswas et al. (2007) who concluded that, moderate supplementation of dietary vit. E may be beneficial for foam production, cloacal 
gland and improve the semen characteristics in male Japanese quail. Also, with those of Biswas et al. (2009) concluded that, moderate supplementation of dietary vitam. E may be beneficial effect for physical and biochemical characteristics of semen in Indian reared kadaknath cookerels.

\section{Conclusion}

In conclusion, from the results of the present work, it is advised that supplementing Japanese quail breeder diet with vitamins $\mathrm{A}, \mathrm{E}$ and $\mathrm{C}$ improved the productive performance, while vit. $\mathrm{B}_{6}$ and $\mathrm{B}_{12}$ gave the higher hatchability Percentage. The best semen characteristics were obtained by vitam. E supplementation.

\section{REFERENCES}

Abd El-Galil, M.A and M.H. Abd El-Samad (2004). Effect of vitamin E, C, Selenium and Zinc supplementation on reproductive performance of two local breeds of chickens under hot climate conditions. Egypt. Poult. Sci., 24 (1): 217-229.

Abdel-Fattah, S.A. and F. Abdel-Azeem (2007). Effects of vitamin E, thyroxine hormone and their combination on humoral immunity, performance and some serum metabolites of laying hens during summer season. Egypt. Poult. Sci., 27: 335- 361.

Abdel-Maksoud, A.A.A. (2006). Effect of vitamin $\mathrm{E}$ supplementation on performance of laying hens during summer months under the desert conditions. Egypt. Poult. Sci., 26: 873-889.

Abdou, M.S.S. (2009). Immunophysiological studies on the effect of some antioxidants in poultry. M.Sc. Thesis, Fac. Agric., Ein Shams Univ., Egypt.

Abou-Kassem, D.E.E. (2010). Managerial studies on Japanese quail performance under Egyptian conditions. Ph.D. Thesis, Fac. Agric., Zagazig Univ., Egypt.

Aburto, A. and W.M. Britton (1998). Effects and interactions of dietary levels of vitamins $\mathrm{A}$ and $\mathrm{E}$ and cholecalciferol in broiler chickens. Poult. Sci., 77 : 666-673.
Ajakaiye, J.J., M.M. Cuesta and J.R. GarciaDiaz (2011). Vitamins C and E can alleviate adverse effects of heat stress on live weight and some egg quality profiles of layer Hens. Pak. Vet. J., 31: 1- 5.

Amiri, A.M., M. Shivazad, S.A. Pourbakhsh, M. Afshar, H. Rokni, N.E. Shiri, A. Mohammadi and Z. Salahi (2006). Effects of vitamin E in broiler breeder diet on hatchability, egg quality and breeder and day old chick immunity. Pak. J. Biol. Sci., 9:789-794.

An, S.Y., Y.M. Guo, S.D. Ma, J.M. Yuan and G.Z. Liu (2010). Effects of different oil sources and vitamin $\mathrm{E}$ in breeder diet on egg quality, hatchability and development of the neonatal offspring. Asian-Aust. J. Anim. Sci., $23: 2: 234-239$.

Biswas, A., J. Mohan and K.V. Sastry (2009). Effect of higher dietary vitamin E concentrations on physical and biochemical characteristics of semen in Kadaknath cockerels. Br. Poult. Sci., 50: 733-738.

Biswas, A., J. Mohan, K.V. Sastry and J.S. Tyagi (2007). Effect of dietary vitamin $\mathrm{E}$ on the cloacal gland, foam and semen characteristics of male Japanese quail. Theriogenol., 67: 259-263.

Bollengier, L.S., M.A. Mitchell, D.B. Utomo, P.E.V. Williams and C.C. Whitehead (1998). Influence of high dietary vitamin $\mathrm{E}$ Supplementation on egg production and plasma characteristics in hens subjected to heat stress. Br. Poult. Sci., 39:106-112.

Burrows, W.H. and J.P. Quinn (1937). The collection of spermatozoa from the domestic fowl and turkey. Poult. Sci., 26 (1): 19-24.

Ciftci, M., O. NihatErtas and T. Guler (2005). Effects of vitamin $\mathrm{E}$ and vitamin C dietary supplementation on egg production and egg quality of laying hens exposed to a chronic heat stress. Rv. Med. Vet., 156: 107-111.

Desoky, A.A. (2008). Effect of dietary vitamin $\mathrm{C}$ and $\mathrm{E}$ supplementation on performance of laying hens under high environmental temperature. Egypt. Poult. Sci., 28: 489-500. 
Donoghue, A.M. and D.J. Donoghue (1997). Effects of water and lipid soluble antioxidants on turkey peroxidation, and functional parameters in ram sperm. Mol. Reprod. Dev., 74: 878-892.

Dreiling, E.C., F.S. Carman and D.E. Brown (1991). Maternal endocrine and fetal metabolic responses to heat stress. J. Dairy Sci., 74:312-327.

Duncan, D.B. (1955). Multiple Range and Multiple F Tests. Biomet., 11: 1-42.

EFSA (2009) Scientific opinion on the substantiation of health claims related to vitamin $\mathrm{B}_{12}$ and red blood cell formation (ID 92, 101), cell division (ID 93), energyyielding metabolism (ID 99, 190) and function of the immune system (ID 107) pursuant to Article 13(1) of Regulation (EC) No 1924/2006. EFSA J., 7 (9): 1223.

EFSA (2010) Scientific opinion on the substantiation of health claims related to vitamin $\mathrm{B}_{12}$ and contribution to normal neurological and psychological functions (ID 95, 97, 98, 100, 102, 109), contribution to normal homocysteine metabolism (ID 96, 103, 106), maintenance of normal bone (ID 104), maintenance of normal teeth (ID 104), maintenance of normal hair (ID 104), maintenance of normal skin (ID 104), maintenance of normal nails (ID 104), reduction of tiredness and fatigue (ID 108), and cell division (ID 212) pursuant to Article 13(1) of Regulation (EC) No 1924/2006. EFSA, J 8 (10): 1756.

Eid, Y., T. Ebeid, M. Moawad and M. El-Habbak (2002). Reduction of dexamethasone-induced oxidative stress and lipid peroxidation in laying hens by dietary vitamin $\mathrm{E}$ supplementation. Emir J. Food Agric., 20 (2): 28-40

El-Mallah, G.M., S.A. Yassein, M.A.F. Magda and A.A. El-Ghamry (2011). Improving performance and some metabolic responses by using some antioxidants in laying diets during summer season. J. Am. Sci., 7: 217-224.

El-Sheikh, S.E.M., and A.A. Salama (2010). Effect of vitamin $C$ and $E$ as water additives on production performance and egg quality of heat stressed local laying hens in Siwa Oasis. Egypt. Poult. Sci., 30: 679- 697.

Engelmann, D., I. Halle, H.W. Rauch, H.P. Sallmann and G. Flachowsky (2001). Influences of various vitamin E supplements on performance of laying hens. Arch Geflügelk., 65: 182-186.

Ezzat, W., M.S. Shoeib, S.M.M. Mousa, A.M.A. Bealish and Z.A. Ibrahiem (2011). Impact of betaine, vitamin $\mathrm{C}$ and folic acid supplementations to the diet on productive and reproductive performance of matrouh poultry strain under Egyptian summer condition. Egypt. Poult. Sci., 31: 521-537.

Fu, Z., H. Kato and K. Sugahara (2000). Retinoic acid accelerates the development of reproductive organs and egg production in japanese quail (Coturnix coturnix japonica). Biol. Reprod., 63 (6): 1795-1800.

Fujihara, N. and B. Howarth (1978). Lipid peroxidation in fowl spermatozoa. Poultry Sci., 57 (11): 66 - 68.

Gonzalez, V.A.D., B.P.A. Contreras, R. Klein and H. Bohmwald (1995). Effect of vitamin $\mathrm{C}$ and $\mathrm{E}$ supplementation in the diet of broiler chicks on performance and immune response. Vet., 26: 333-340.

Gore, A.B. and M.A. Qureshi (1997). Enhancement of humoral and cellular immunity by vitamin $\mathrm{E}$ after embryonic exposure. Poult. Sci., 76:984-991.

Grobas, S., J. Mendez, C. Lopez Bote, C. De Blas and G.G. Mateos (2002). Effect of vitamin $\mathrm{E}$ and $\mathrm{A}$ supplementation on egg yolk $\alpha$-Tocopherol concentration. Poult. Sci., 81: 376-381.

Hackett, A.J. and J.W. Macpherson (1965). A method for differential staining of bovine spermatozoa after extension in sterile milk. Can. Vet. J., 6: 117-120.

Halle, I. and M. Ebrahem (2012). Influence of Vitamin $\mathrm{B}_{12}$ and Cobalt on performance of laying hens. Landbauforschung - vTI Agric. and Forestry Res., 62 (3): 111-116.

Hood, J.E. (1999). An attempt at alleviating heat stress infertility in male broiler breeder chickens with dietary ascorbic acid. M.Sc. 
Thesis. Mississippi State Univ., Mississippi State, MS.

Hooda, S., K.T. Praveen, J. Mohan, A.B. Mandal, A.V. ELangovan and K.T. Pramod (2007). Effects of supplemental vitamin $\mathrm{E}$ in diet of Japanese quail on male reproduction, fertility and hatchability. Brit. Poult. Sci., 48: 104-110.

Jabbar, A., W. Abbass, A. Riaz, A. Sattar and M. Akram (2015). Effect of different concentrations of ascorbic acid on semen quality and hatchability of indigenous aseel chicken. J. Anim. and Plant Sci., 25 (5): 1222-1226.

Jena, B.P., N. Panda, R.C. Patra, P.K. Mishra, N.C. Behura and B. Panigrahi (2013). Supplementation of vitamin $\mathrm{E}$ and $\mathrm{C}$ reduces oxidative stress in broiler Breeder hens during summer. Food and Nut. Sci., 4: 33-37.

Kafri, U. (1989) Fluorine enrichment in groundwater recharged through dust deposits, southern Israel [J]. J. Hydrol., 110: 373-376.

Kaiser, M.G., S.S. Block, C. Ciraci, W. Fang, M. Sifri and S.J. Lamont (2012). Effects of dietary vitamin $\mathrm{E}$ type and level on lipopolysaccharide induced cytokine mRNA expression in broiler chicks. Poult. Sci., 91 (8): 1893-1898.

Kutlu, H.R. and J.M. Forbes (1993). Changes in growth and blood parameters in heat-stressed broiler chicks in response to dietary ascorbic acid. Livestock Prod. Sci., 36: 335-350

Lin, H., L.F. Wang, J.L. Song, Y.M. Xie and Q.Y. Yang (2002). Effect of dietary supplemental levels of vitamin A on the egg production and immune responses of heatstressed laying hens. Poult. Sci., 81:458-465.

Lin, Y.F., H.L. Tsai, Y.C. Lee and S.J. Chang (2005). Maternal vitamin E supplementation affects the antioxidant capability and oxidative status of hatching Chicks, J. Nut., 135 (10): 2457- 2461.

Mahmoud, K.Z., M.M. Beck, S.E. Scheideler, M.F. Forman, K.P. Anderson and S.D. Kachman (1996). Acute high environmental temperature and calcium- estrogen relationship in the hen. Poult. Sci., 75:1555-1562.

Marin-Guzmen, J., D.C. Mahan, Y.K. Chung, J.L. Pate and W.F. Pope (1997). Effects of dietary selenium and vitamin $\mathrm{E}$ on boar performance and tissue responses, semen quality and subsequent fertilization rates in mature gilts. J. Anim. Sci., 75: 2994 - 3003.

McDowell, L.R. (1989). Vitamins in Animal Nutrition. Comparative Aspects to Human Nutrition. Vitamin A and E. Mc Dowell L.R. (ed.) Academic Press London, 10 (52): 93131.

McMurry, C.H., W.J. Blanchflower and D.A. Rice (1980). Influence of extraction techniques on the determination of $\alpha$ tocopherol in animal feedstuffs. J. Assoc. Off. Anal. Chem., 63: 1258-1261.

Monsi, A. and D.O. Onitchi (1991). Effects of ascorbic acid (vitamin C) supplementation on ejaculated semen characteristics of broiler breeder chickens under hot and humid tropical conditions. Anim. Feed Sci. Tech., 34:141.

Moreng, R.E. (1980). Temperature and vitamin requirements of the domestic fowl. Poult. Sci., 59: 68-77.

Nayaka, H.B.S., B. Umakantha, S.W. Ruban, H.N. Murthy and H.D. Narayanaswamy (2012). Effect of neem, turmeric, vitamin E and their combinations on immune response in broilers. Glob Vet., 9 (4): 486-489.

Noll, S.L. (1997). Vitamin C for turkey breeders. Proc. of the Arkansas Nutrition Conf., Arkansas Poult. Federation, Little Rock, Arkansas.

NRC (1994). National Research Council. Nutrient Requirements of Poultry $9^{\text {th }} \mathrm{Ed}$. Nat. Acad. Sci. Washington, DC., USA.

Orban, J.I., D.A. Ronald, Jr.K. Cummins and R.T. Lovell (1993). Influence of large doses of ascorbic acid on performance, plasma calcium, bone characteristics and egg shell quality in broiler and leghorn hens. Poult. Sci., 72:691-700.

Pavlik, A., M. Lichovnikova and P. Jelinek (2009). Blood plasma mineral profile and 
qualitative indicators of the eggshell in laying hens in different housing systems. Acta Vet. (Brno), 78 : 419-429.

Pond, W.G., D.C. Church and K.R. Pond (1995). Folic acid. In: Basic Animal Nutrition and Feeding, $4^{\text {th }}$ Ed. Wiley, New York, NY.

Sahin, K. and O. Kucuk (2001). Effects of vitamin $\mathrm{C}$ and vitamin $\mathrm{E}$ on performance, digestion of nutrients, and carcass characteristics of Japanese quails reared under chronic heat stress $\left(34^{\circ} \mathrm{C}\right)$. J. Anim. Physiol. Anim. Nut., 85 (11-12): 335-342.

Sahin, K., N. Sahin and M. Onderci (2002a). Vitamin E supplementation can alleviate negative effects of heat stress on egg production, egg quality, digestibility of nutrients and egg yolk mineral concentrations of Japanese quails. Vet. Sci., 73: 307-312.

Sahin, K., N. Sahin, M. Onderci, M.F. Gursu and M. Issi (2003). Vitamin C and E alleviate negative effects of heat stress in Japanese quails. Food, Agric. Environ., 1 (2): 244-249.

Sahin, K., N. Sahin, M. Onderci, S. Yaralioglu and O. Kucuk (2001). Protective role of supplemental vitamin $\mathrm{E}$ on lipid peroxidation, vitamins $\mathrm{E}, \mathrm{A}$ and some mineral concentrations of broilers reared under heat stress. Vet. Med.-Czech., 46 (5): 140-144.

Sahin, K., O. Kucuk, N. Sahin and M. Sar1 (2002b). Effects of vitamin C and vitamin E on lipid peroxidation status, some serum hormone, metabolite, and mineral concentrations of Japanese quails reared under heat stress $\left(34^{\circ} \mathrm{C}\right)$. Int. J. Vitam. Nutr. Res., 72 (2): 91-100.
SAS Institute (1996). SAS User's Guide. Version 6.12. SAS Institute Inc., Cary, NC.

Selim, Sh.A., K.M. Gaafar and S.S. El-ballal (2012). Influence of in ovo administration with vitamin $\mathrm{E}$ and ascorbic acid on the performance of Muscovy ducks. Emir. J. Food Agric., 24 (3): 264-27.

Siegel, H. S. (1995). Stress, strains and resistance. Br. Poult. Sci., 36:3-22.

Snedecor, J.P. and W. Cochran (1982). Statistical Methods. $7^{\text {th }}$ Ed. Aims, USA, The Iowa State Univ., 507.

Sönmez, M., G. Türk and A. Yüce (2005). The effect of ascorbic acid supplementation on sperm quality, lipid peroxidation and testosterone levels of male Wistar rats. Theriogenol., 63 : 2063- 2072.

Taylor, T.G. and C.G. Drake (1984). Calcium metabolism and its regulation in: Freeman, B.M.(Ed.) Physiology and Biochemistry of the Domestic Fowl. 5:125 -170 (London, Academic Press).

Teeter, R.G. (1995). Effects of feed intake and fasting duration upon body temperature and survival of thermo stressed broilers. Nut. Rep. Int., 35: 531- 537.

Tojo, H. and T.M. Huston (1980). Effects of environmental temperature on the concentration of serum ostradiol, progesterone, and calcium in maturing female domestic fowl. Poult. Sci., 59 : 27972802.

Yanming, H. and D.H. Baker (1993). Effects of sex, heat stress, body weight and genetic strain on the dietary lysine requirements of broiler chicks. Poult. Sci., 72:701-708. 


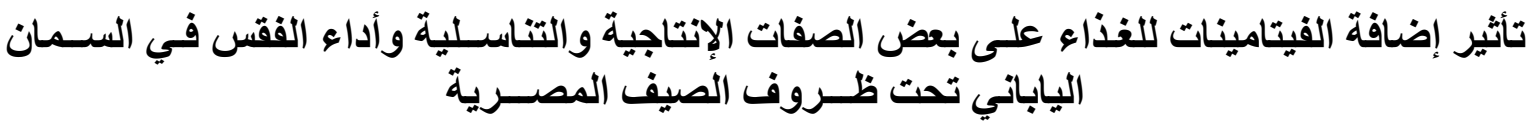

محمد ممدوح المكاوي - علي عبد الرازق عسكر - زينات عبد الجواد إبراهيم - مصطفي محمد سليمان

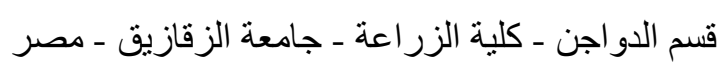

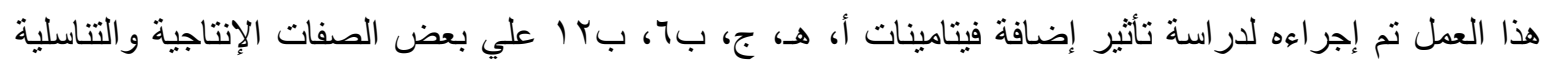

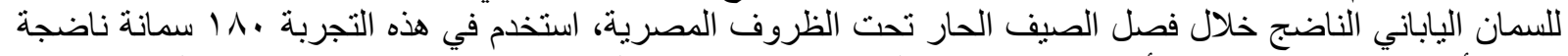

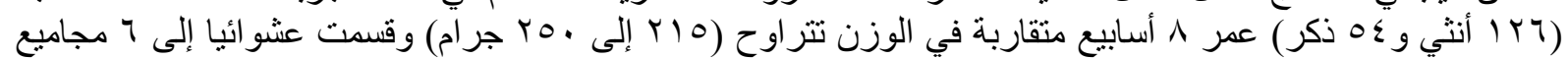

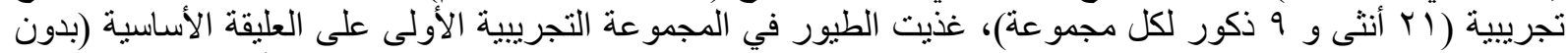

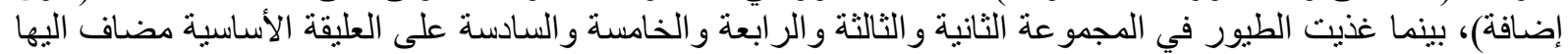

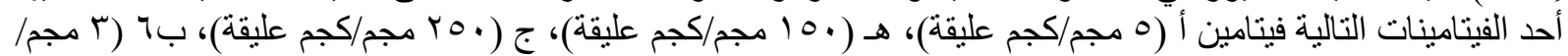

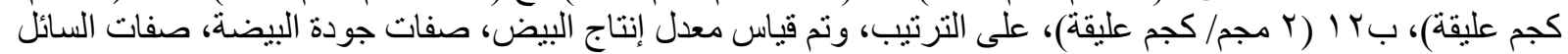

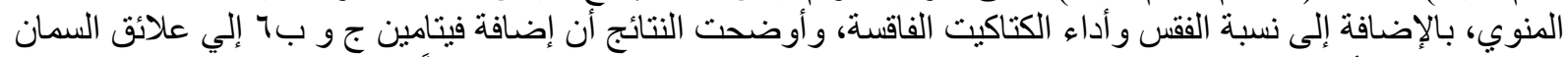

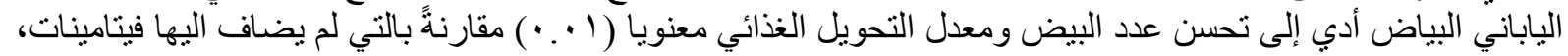

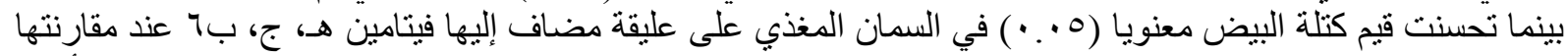

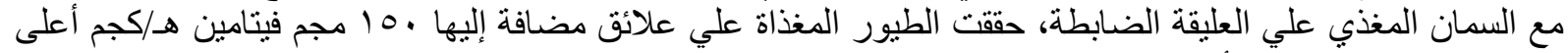

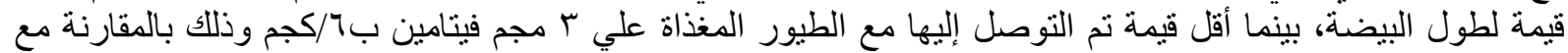

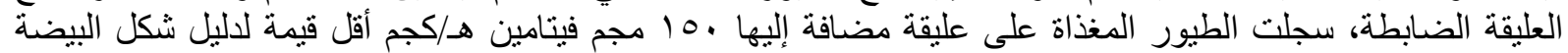

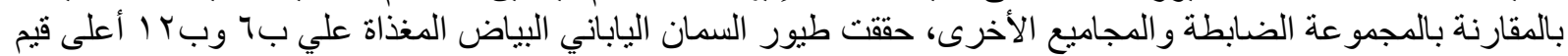

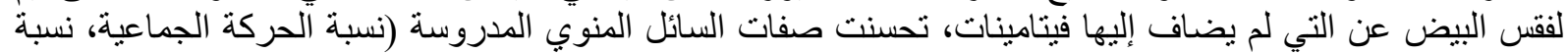

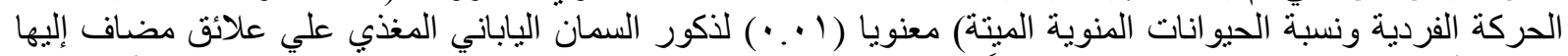

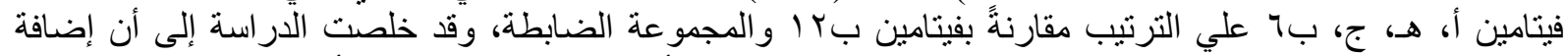

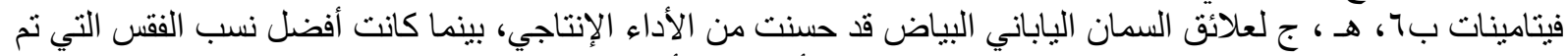

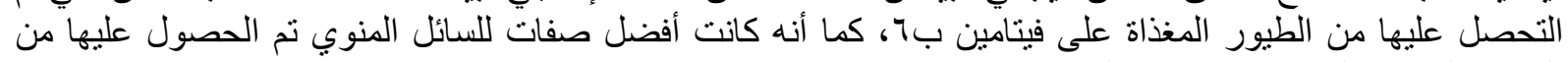

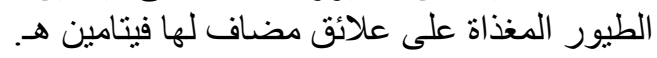

أستاذ الفسيولوجي المتفرغ - كلية الطب البيطري - جامعة الزقازيق.

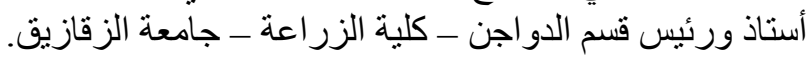

